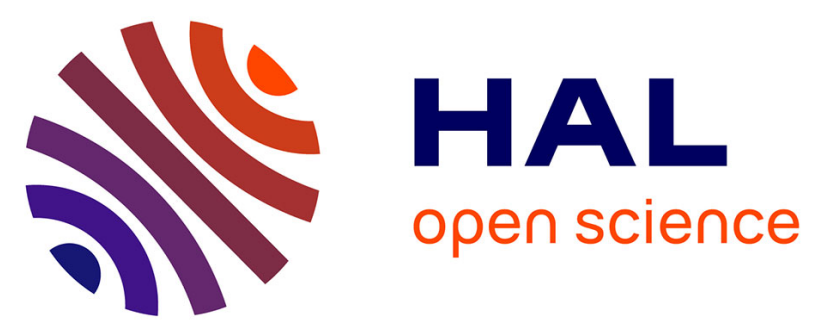

\title{
Assessment of Machine Learning Algorithms for Near-Sensor Computing Under Radiation Soft Errors
}

Matheus Garay Trindade, Rafael Garibotti, Luciano Ost, M. Letiche, J. Beaucour, Rodrigo Possamai Bastos

\section{- To cite this version:}

Matheus Garay Trindade, Rafael Garibotti, Luciano Ost, M. Letiche, J. Beaucour, et al.. Assessment of Machine Learning Algorithms for Near-Sensor Computing Under Radiation Soft Errors. 16th International School on the Effects of Radiation on Embedded Systems for Space Applications (SERESSA 2020), Dec 2020, Porto Alegre (Virtual edition), Brazil. hal-03100531

\section{HAL Id: hal-03100531 \\ https://hal.science/hal-03100531}

Submitted on 3 Feb 2021

HAL is a multi-disciplinary open access archive for the deposit and dissemination of scientific research documents, whether they are published or not. The documents may come from teaching and research institutions in France or abroad, or from public or private research centers.
L'archive ouverte pluridisciplinaire HAL, est destinée au dépôt et à la diffusion de documents scientifiques de niveau recherche, publiés ou non, émanant des établissements d'enseignement et de recherche français ou étrangers, des laboratoires publics ou privés.

\section{(ㄷ)(1) $\$$}

Distributed under a Creative Commons Attribution - NonCommerciall 4.0 International 
